\title{
Journal of the British Archaeological Association
}

\section{Seeking Salvation: Commemorating the Dead in the Late-Medieval English Parish}

\section{Meg Bernstein}

To cite this article: Meg Bernstein (2017) Seeking Salvation: Commemorating the Dead in the Late-Medieval English Parish, Journal of the British Archaeological Association, 170:1, 220-222, DOI: $10.1080 / 00681288.2017 .1366742$

To link to this article: https://doi.org/10.1080/00681288.2017.1366742

曲 Published online: 20 Nov 2017.

Submit your article to this journal $\pi$

Џ Article views: 2

Q View related articles $₫$

View Crossmark data $₫$ 


\section{Reviews}

uphill part of the city, starting with those which were attached to the remains of the former Roman south gate. The fact that houses in this book were outside the privileged world of the cathedral canons did not result in any diminution in the quality of their architecture. Indeed, the two I2th-century stone houses, the Magna Aula of Joan of Legbourne (46-47 Steep Hill and I Christ's Hospital Terrace) and the Jew's House (I 5 Strait and I Steep Hill), are among the most important examples of stone domestic architecture in Europe. The buildings of Steep Hill may be physically separated from the cathedral Close, but the cathedral's archives are still a rich source for the investigation of these buildings. The fact that many of these properties were given to the cathedral as chantry bequests means that in some instances there is documentary evidence for ownership extending back to the I2th century.

It is not possible in reviewing this book to ignore the evidence it provides about the world of the Jews in Lincoln between the I 2 th century and their expulsion from England in I298. The meticulous survey of documents (Lincoln cathedral records, the National Archives and the Jewish Starrs preserved in the Muniment Room of Westminster Abbey) yield evidence of the Jewish ownership of houses on Steep Hill, showing also that Christians and Jews lived next to each other and collaborated in property management, even after the executions of Jews following the alleged murder of Little St Hugh in I255. In particular, the authors have been able to offer a new interpretation of the site known as the Jews' Court ( 3 Steep Hill) and to prove conclusively that before the Expulsion it incorporated a synagogue.

The skill with which the histories of the houses of the Steep Hill are stitched together from documentary evidence is matched by the painstaking recreation of their physical appearance by Stanley Jones. Future historians will owe a debt of gratitude to his work of analysing and recording such important sites as the timber-framed building I9-22 Steep Hill, known as The Harlequin (the first investigation and assessment of this wellknown landmark). It is to be hoped that the work done for this publication will ensure the future conservation and interpretation of this and similar buildings.

The benefit to the readers of this book lies in the fact that the material is presented topographically rather than chronologically or by type. It is therefore possible to survey the changing demographics of ownership and occupation over the centuries of buildings whose outward appearance changed according to prevailing fashions but whose inner structural skeleton, as revealed by Stanley Jones, often stayed the same.

LESLEY MILNER

(C) 2017 Lesley Milner

DOI IO.IO80/0068I288.20I7.I36674I

Check for updates

Seeking Salvation: Commemorating the Dead in the Late-Medieval English Parish. By SAlLy BadHam.

Donington, Shaun Tyas, 20I5. ix +278 pp., II 8 col. illus. ISBN 978-I-907730-47-4. $£_{39.95}(\mathrm{hb})$

Death could never be far from one's mind in the medieval parish church. Altars were required to contain relics, usually fragments of the bodies of the saintly dead; every mass invoked Christ's death and resurrection. In addition to these more intangible elements, physical reminders of death were everywhere: monumental brasses remembered the dead at ground level. Sculptural effigies crowded into nave aisles, chantry chapels or, for the luckiest, in the chancel itself, and served as reminders of dead community members and 
one's own impending mortality. In spite of the wealth of surviving visual mnemonics for commemoration that England's parish churches have to offer, modern visitors lack the full picture of the death-preparatory piety of the Middle Ages. Eucharistic vessels, paintings, sculpture and other objects have been lost to time, Reformation, reuse and reordering. Seeking Salvation employs surviving objects and extant documents to explore the material aspects of memoria in the parish church, considering the various strategies employed by the pre-Reformation laity to protect their souls in the afterlife. In this book Badham considers not only with monuments - the focus of her existing oeuvre - but also philanthropic good works enacted in preparation for death and pious donations for church fabric and fittings, service books, vestments and altar objects.

The subject is potentially vast; there are some 8,000 medieval English parish churches, and Badham does not limit herself to only one region. The limit, instead, is imposed by the data, the author relying on extant probate evidence (particularly wills), with the bulk of her case studies dating from the I5th and I6th centuries. The book's twelve chapters can be placed in subgroups. The first three provide an introduction to the sources, as well as the social and theological context for memoria. This section includes a summary of Jacques Le Goff's The Birth of Purgatory, the seminal scholarly work on the doctrine of Purgatory and concepts of intercession and indulgences, a topic which forms a cornerstone of Badham's evaluation of memoria. Though most readers will be familiar with these concepts, they are critical for understanding the commemorative impulses discussed in the pages that follow, so the review of Le Goff is worthwhile and justified. Following this introductory section, the fourth chapter, 'Philanthropic Good Works in the Community', essentially stands alone. In this chapter, Badham analyses donations made during the lifetime of the donor outside of the context of the parish church, including almsgiving, donations to hospitals, schools, care of bridges and roads and other municipal works. These, she argues, manifested both a religious imperative and social responsibility (p. 39), though there were doubtless spiritual benefits on offer as well. For example, Archbishop Walter de Grey granted an indulgence for contributors to the Wetherby Bridge in 1233 (p. 56). By and large, however, even though these projects did not have a directly Christian function, donors seem to have desired to be remembered by their communities for good works, both in their prayers and otherwise.

Chapters 5, 6 and 7 consider charitable donations to the church that 'included devotional and instructional iconography of value to the entire community' (p. 9). In Chapter 5 , Badham discusses donations to building fabric both by individuals (for example, Ingham, Norfolk), and collaborative patrons (examples include Long Melford, Norfolk and Lewisham, Kent). Chapter 6 is devoted to church fittings, including paintings, roods, screens and glazing. Chapter 7, 'Church Ornaments', investigates the movable objects provided for the church: textiles such as vestments and altar cloths, as well as service books and altar plate.

Although it was certainly the hope of individual donors that these pious acts would have brought them spiritual favour and prayers from their community, Chapters 8 to II focus particularly on funding provisions that are directly related to ensuring prayers for one's soul. Chapter 8 considers the foundation of collegiate churches and chantries to provide directed prayer for individuals or families; Chapter 9 expands on this base to include religious guilds. The subjects of Chapters Io and II are funerals, burial location and monuments. As much as is possible, Badham uses documents to elucidate not only the donations and monuments of the wealthy, but also people of more middling means who commissioned humbler monuments (or made a provision for extramural burial rather than the more prestigious intramural interment). 


\section{Reviews}

The final chapter, 'Reactions', is a conclusion both to the book and the period. It deals with suspicion of the Church's intimation that purgatorial time could be quickly reduced through good works or post-mortem prayer. In particular, Badham considers the Lollards' claims of corruption in the Church (a response primarily to the conspicuous monumentalisation for people of means) and the English Reformation, which initiated the destruction of church decoration, fittings and monuments and caused significant shifts in the aesthetics of parish churches and the experience of worship.

Seeking Salvation is well produced and amply illustrated (primarily with C. B. Newham's high-quality images of tombs, brasses and wall-paintings.) It is a shame, however, that manuscript illuminations discussed in depth in the text, for instance the funeral cortège of Alexander the Great (Paris, Petit Palais MS Dutuit 456), are not reproduced.

The documentary focus on the laity means this book is a useful addition to the existing literature on monuments, including the studies by Saul, Burgess, Duffy and Marks. Though Badham's book is impressive in its thorough consideration of extant documents, it misses the opportunity to discuss some important thematic issues, for instance that wills and other documents relating to burial provide some of the best evidence of female agency in the Middle Ages. Badham does indeed record the funerary and commemorative requests of many women, among them Dame Katharine Harcourt (p. 8), Lady Anne Danvers (p. I09), Dame Maud Spicer (p. I 16), Mawde Undirhill (p. I24), Elizabeth Speke (p. I27), Margarete Asshcombe (p. I88) and Joan, lady of Cobham (p. 255). Many of these individuals were widows, who, among uniquely for women, had the privilege of legal rights over their estates. These documents provide a rare glimpse at the lives of women in the Middle Ages; it is disappointing that Badham does not address this, nor does she cite the work of Katharine L. French, author of The Good Women of the Parish: Gender and Religion After the Black Death (University of Pennsylvania Press 2007).

A possible criticism is that Badham's book offers few surprises. The author does not make any effort to resist English parochialism by bringing in comparative material from the Continent or elsewhere in the British Isles, nor does Badham diverge from traditional methodologies or approaches. However, the predictability of book's conclusions is a sign of the author's rigorous research. The book's strength is its foundation on thorough analysis of the extant documents; Badham has reviewed hundreds of these, and long extracts are discussed in the text. Although early modern English has been transcribed in its original form, Latin texts are both transcribed and translated for the reader's convenience. She offers some caveats to the study of probate texts at the outset, and these help the reader to look critically at the evidence cited. She asserts that wills represent only a particular moment in time when a person requested something, not necessarily their lifelong opinions, nor their desires at the time of death; secondly, she specifies that there was no guarantee the executors of wills always carried out the wishes of the testator (there are plenty of examples where the monument requested cannot be found, for example York merchant Nicholas Blackburn's supposed monument at All Saints North Street, p. 2I3). In summary, Badham's book provides a useful framework for understanding the varieties of ways that people made provisions for their souls in the later Middle Ages in England.

MEG BERNSTEIN

(C) 2017 Meg Bernstein

DOI IO.I080/0068I288.20I7.I366742 